\title{
Performing Femininity in Japanese Politics: Chikage Ōgi Case Study
}

\author{
ALISON LUKE \\ Macquarie University
}

\section{ABSTRACT}

Women's access to the political sphere in Japan has been limited by structural constraints which perpetuate their roles primarily as housewives and mothers. Some women who seek to become professional politicians use these images of traditional femininity as a deliberate tactic in political campaigns to provide a culturally acceptable way for them to express their political views. This paper analyses the life of Chikage Ōgi, a Japanese politician who was once a Takarazuka actress, in order to develop a deeper understanding of the ways in which gender-role expectations restrict women's access to opportunities throughout their life course and the pragmatic ways that women strive to achieve their goals despite this. Ögi used the performance skills she developed during her time as an actress to enhance her political image and fulfil her political ambitions. This paper highlights Ögi's creativity in enacting agency in Japan's male-dominated political sphere and demonstrates the complex ways she both upheld and subverted gender norms in order to achieve political longevity.

\section{KEYWORDS}

Chikage Ōgi; femininity; gender; history; politics; performance; Takarazuka; women
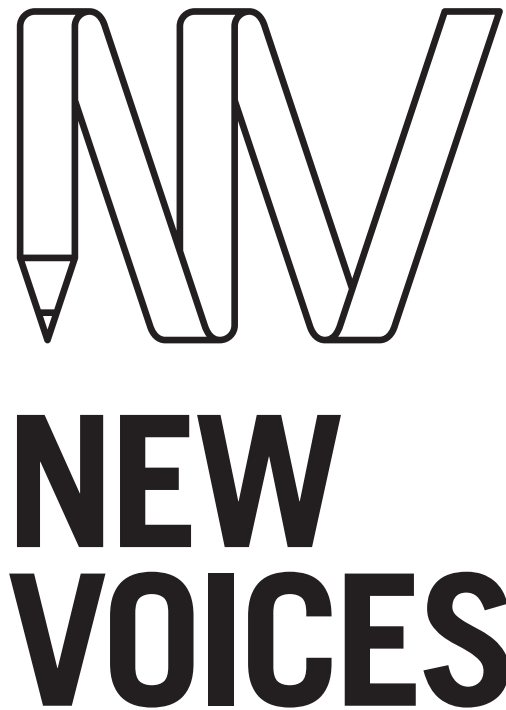

IN JAPANESE STUDIES

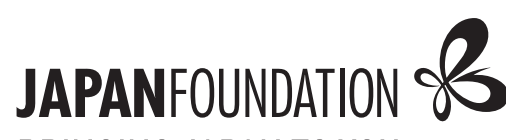

BRINGING JAPAN TO YOU

To link to this article:

http://dx.doi.org/10.21159/nvjs.08.06

\section{ISSN 2205-3166}

New Voices in Japanese Studies is an interdisciplinary, peer-reviewed journal showcasing the work of emerging scholars from Australia and New Zealand with research interests in Japan.

All articles can be downloaded free at newvoices.org.au

(c) The Japan Foundation, Sydney and Alison Luke, 2016

\section{(c) (1) $(-)$}




\section{INTRODUCTION}

Japanese politics have long been dominated by men, and the presence of women in the political sphere is treated as both a novel and unnatural occurrence. This is particularly the case in conservative political parties that wish to maintain the status quo of Japan's “old-boys club” (Mackie 1989; Dalton 2008a). Many scholars have noted persistent gender inequality in Japan's political system as women continue to be under-represented in politics (Dalton 2015; Eto 2010; Tachibanaki 2010). Although this is by no means unique to Japan, it is notable that women are often subjected to gender-based criticism and public heckling by male politicians motivated by an underlying belief in women's primary roles as housewives and mothers (Japan Today 2014; Dalton 2008a). The existence of such social norms and gender roles places women at a significant disadvantage because they restrict women's access to resources and support systems throughout their life course which may otherwise enable them to ascend to positions of power and realise their goals. In the political world, women's lack of access to inner circles of power in general has meant that female politicians are kept out of association with "dirty" politics and are connected with an image of "clean" politics (Derichs et al. 2006, 248; see also Iwao 1993). This image persists, even though some powerful female politicians (i.e., cabinet ministers) have been involved in political scandals. It persists because, in the dominant gender discourse, women have continued to be perceived as political outsiders, such that "men are the norm and women are the 'other"' (Dalton 2015, 99; see also Dalton 2011).

Political parties comprising mainly of male members have exploited female politicians as "token" candidates in their political campaigns (Rosenthal 2008) and prefer to limit their political involvement to areas deemed appropriate for women. Utilising women as political assets distracts voters with an image of change or reform without actually improving women's status. This has tended to reinforce stereotypes about women's political (in)ability, as the majority of candidates fielded in this manner are not re-elected. Male-centric political parties seem unconcerned by issues of gender equality, and view women's political presence as a way to reinforce social norms through political rolemodeling while constructing an image that may appeal to more voters.

This paper explores the career of Chikage Ōgi ${ }^{1}$ [扇 千景; b. 1933], a former performer with the Takarazuka Revue (an all-female musical theatre company), actor and television host who became a politician. Her career highlights the ways that political parties, and indeed female politicians themselves, utilise idealised femininity to achieve political objectives. It examines the way that Ögi, like many other women, responded to a male-dominated political culture by leveraging gender norms and her normative roles as a housewife and mother of two to show her suitability and trustworthiness to her electorate. However, while Ōgi adopted a typical feminine image in her demeanour and attire, aspects of her behaviour demonstrate a rejection of gender norms. Ōgi's 
political tactics, if not her political direction, have been strongly connected with her early life experiences where she developed an understanding of the value of gender performativity through her family and her Takarazuka training.

The first section of this paper introduces Ōgi's pre-political experiences, using a feminist understanding of the 'life course'. This concept pertains to gendered ways in which socio-cultural contexts restrict access to opportunities (Bengsten and Allen 1993, 492-93). It is used here to analyse the way Ögi enacted agency within these constraints to overcome the challenges she faced. This framework helps to understand the gendered challenges women face in Japan, and how these can manifest in politics. It draws on the four main ontological assumptions underpinning a life course perspective as defined in the work of Elder (1998) and summarised below:

1. An individual's opportunities and constraints are influenced by and must be understood within their cultural and historical contexts;

2. There is an interdependency between the individual and their close relations (i.e., family/friends), recognising the family as the basis of socialisation;

3. Individuals have agency and enact choices within the constraints and expectations of their cultural and historical circumstances;

4. The timing of events, including turning points and transitions, has immediate and long-term effects on the trajectory of the life course.

The final section of this paper discusses Ögi's political career and how her prior life experiences are reflected in her political performance. This will include a visual analysis of Ögi's appearance in a selection of Cabinet photographs from 2000 to 2002 which compares Ōgi with her female colleagues. While a detailed analysis of Ōgi's political decisions and policies is beyond the scope of this paper, I will argue that this illustrates the way that Ögi has maintained certain social expectations through her presentation as 'feminine', even though her actions often subverted such gender norms.

\section{INFLUENCE OF FAMILY ON EARLY LIFE EXPERIENCES}

Ōgi's early childhood experiences and family attitudes played a large role in shapingherself-perception and lifegoals. Thelife-courseperspectiveemphasises the importance of childhood in determining access to opportunities due to cumulative advantage or disadvantage (Hutchinson 2001). Ögi's position as a daughter in a family that supported the maintenance of traditional gender roles determined her access to education and work opportunities. According to Ōgi, her personal wartime experiences also exercised a lasting impact by motivating her to pursue peace in her political career. I will analyse aspects in Ögi's early life as they influenced the development of her character and future career goals. 
Chikage Ögi was born in Kobe in Hyogo prefecture on 10 May 1933, as the third daughter of Matsutarō (father) and Misae (mother) Kimura. She was born in a time of fervent nationalism during the Meiji period [1868-1912] which culminated in Japan's participation in the Second Sino-Japanese War [19371945] and the Pacific War [1941-1945] (Morton and Olenik 2005). As Japan's expansion throughout Asia-Pacific was driven back, the Allies launched a series of attacks from the air and sea on mainland Japan, which included Ōgi's hometown of Kobe (United States Strategic Bombing Survey 1947). Eleven yearold Ōgi survived. As Ōgi identified, "this [evacuation] experience is my origin as a politician” (この [疎開] 体験こそが、私の政治家としての原点なのです) (Ōgi 2001, 36). ${ }^{2}$ These experiences putatively motivated her to strive for peace and bring an end to warfare (Shimazaki 2006, 62). Actively working towards peace is an important step in protecting both women and men from disadvantage. It also protects women from the exacerbation of existing gender inequality and vulnerability (Banerjee 2010, xvi). These somewhat stereotypical comments of Ōgi's, as favoured by but not limited to female politicians, tend to reinforce associations between 'peace' and femininity (Banerjee 2010, xiii).

Confucian values served an essential role in the construction of gender roles during the Meiji period. This institutionalised the existing ie (家) or stem family system (Ueno 2009), which was central to social organisation in this period. The government considered adherence to these roles as vital in strengthening national identity and economic development toward its multiple war efforts (Nocedo 2012, 2). This was reinforced by a normative division of labour, with men placed at the head of the family as the "bread winners" in the "public sphere" while women were to be good wives and wise mothers who belonged at home in the "private sphere" (Lebra 2007a, 249). Women's educational institutions strongly promoted this as an ideal, even though it was not the reality for many women who had to work outside the home due to economic necessity (Nocedo, 2012; Reitan 2011). The example of Matsutarō and Misae Kimura was no different from this breadwinner/housewife paradigm, as Matsutarō worked as a bank employee while Misae managed the household. Matsutarō Kimura promoted Ōgi's adherence to strict gender roles (Shimazaki 2006,62 ), meaning that approved life choices were limited and she lacked access to opportunities to develop alternate possible selves.

Ōgi's family life was shaped by these values and gendered expectations (Ōgi 2008). Ōgi graduated from Hyogo Prefectural Kobe High School (兵庫県立神 戸高等学校) in 1952 and aspired to enter university (Kobayashi 2014, 52-53). She achieved high grades in her exams and it was recommended that she enrol in Kobe University (神戸大学) (Ōgi 2008, 158). Ōgi wished to enrol in Kobe University's Department of Architecture and become an interior designer but her “father stood in front of such a dream” (そんな夢の前に父の一言が立ちはだ かった) (Ōgi 2008, 158). His disapproval was based on how Ōgi’s choice would negatively affect her ability to uphold gender norms and expectations. Her father disapproved of Kobe University as a mixed-gender institution and told her, "You'll begin to keep bad company so only a woman's college is allowed" (虫がつくから女子大しかダメ) (Shimazaki 2006，62). Ōgi’s father preferred women's colleges as they served to prepare middle-class women for future 
roles as mothers and housewives (Uno 2005). He stated, "If you become a tomboy you won’t become a wife” (おてんばになったら嫁のもらい手がなくなる) (Ōgi 2008, 158). Ōgi's father wished for her to work as a secretary and refused to pay her tuition, thus making her unable to attend university (Kobayashi 2014). In this way, a strong paternal influence in a patriarchal family system can limit a child's access to educational opportunities (Lebra 2007b). This made it difficult for Ōgi to seek a career outside of prescribed gender roles. Under these limiting circumstances, Ōgi went on to enter the Takarazuka Music School (宝塚音楽学校) and Takarazuka Revue (宝塚歌劇団), which ultimately paved the way for her career as a performer and public personality.

\section{BECOMING A TAKARASIENNE}

There was an element of chance in Ögi's decision to enter the Takarazuka Music School in 1952 and become a 'Takarasienne. ${ }^{3}$ As Ōgi "did not have the courage to work part-time to earn the tuition” (アルバイトで学費を稼いで大学 に行く勇気もない) (Ōgi 2008, 158), her friend’s older sister suggested that she try out for Takarazuka Music School and secretly sent in an application on her behalf (Kobayashi 2014). Ōgi had no longing for the entertainment industry and had never thought of performing before, but at her friend's insistence and out of her own curiosity she took an audition (Ōgi 2008, 158-59). She had preferred theatre study group over tennis in high school, and her childhood music and dance lessons served her well (Shimazaki 2006, 62). Although Ōgi was still unsure of her feelings she decided to go ahead and without any preparation she passed the exam (Ōgi 2008, 159). She then succeeded in the interview without knowing any current Takarazuka stars when asked. Her father was furious when she told him she had been accepted into the school and planned to perform in the Revue. Despite this, she completed her training and joined the Takarazuka Revue in 1954, ranking fourth out of the fiftyone students in the 41st graduating class (Kobayashi 2014). Ögi demonstrated agency in this decision, contesting the objections of her parents: "adults had unreasonably restrained me before and now there was a surge in my rebellious spirit”(無理やり抑えにかかる大人たちを前にして、反抗心がわきあがってきた。よ し、それなら宝塚に行ってやる) (Ōgi 2008, 160). Ōgi’s motivation to disobey her father was also due to the decent income offered to performers in the Revue, which would allow her financial independence from her family. This was an important turning point in her life-course trajectory as it offered access to a wider range of opportunities and increased her cultural capital.

The Takarazuka Revue is an all-female performance company established in 1913 by entrepreneur and politician Ichizō Kobayashi [1873-1957] as a business strategy to increase passengers on his railway line to a town of the same name (Robertson 1991). Performers were (and still are) restricted by age, and required to remain unmarried for the duration of their career with the Revue. As was the case with Ōgi, most girls came from privileged backgrounds (i.e., from middle/upper class families) (Robertson 1998) as the two years of group vocal and theatrical training to become a Takarasienne was expensive.

3 'Takarasienne' is a nickname for Takarazuka performers. It plays on 'Parisienne', in acknowledgement of the 
This suggests that Ōgi's parents must have contributed to her tuition despite their objections, although renewed conflict upon her graduation (Ōgi 2008, 160) also suggests that they did not anticipate her actually performing in the Revue.

The Takarazuka Revue (also known simply as 'Takarazuka') is still active and popular in Japan today. It has five performing troupes and their leading stars are designated as either otokoyaku (男役; lit., 'male role') or musumeyaku ( 娘役; lit., 'daughter role'). Performers specialising in either role may later graduate to older female roles, known as onnayaku (女役; lit., 'woman role'). The term 'onnayaku' has also been used by fans and Takarasiennes to elevate musumeyaku to the same status as otokoyaku (Robertson 1992, 182). Takarazuka performances attract an almost entirely female audience (upwards of 90 percent), with large fan bases which develop around the otokoyaku performers (Brau 1990, 80). Singer $(1996,167)$ asserts that the otokoyaku classification is coveted by Takarasiennes because usually only these performers become top stars and can earn the highest wages. Within each of the company's five troupes, a limited number of women are selected as the otokoyaku leads, and they usually remain in these coveted and higherpaid positions for the duration of their careers. Otokoyaku may occasionally be called upon to play strong female roles as well, mainly to capitalise on their popularity. The remaining positions are filled by more junior otokoyaku or those who perform musumeyaku, some of whom become female leads and form a so-called "golden combination"-an otokoyaku and musumeyaku pairing who appear together in many performances (Singer 1996). Others take character roles of either sex.

Ōgi was designated as a musumeyaku performer. These roles allowed her to cultivate a feminine repertoire, utilising codified feminine behaviours such as exaggerated mannerisms, vocalisation and visual cues (Brau 1990, 86). As a musumeyaku, one must focus on cultivating qualities of femininity-such as long hair-that are aesthetically prized in Japan. Musumeyaku must also possess attributes that have come to be valued in Takarazuka's repertoire of femininity and which distinguish them from their otokoyaku counterparts, including a soprano voice and unnaturally high vocalisation, physically restricted and graceful movements, and specific colours and patterns used in costuming-for example, pink (Ueda 1974, 97-9). The Takarazuka motto, “Kiyoku, tadashiku, utsukushiku” (清く、正し<、美しく), meaning "With purity, honesty, [and] beauty," strongly reflects the school's ideals of femininity (Takarazuka Music School 2015). Language use is another point of differentiation between otokoyaku and musumeyaku: once designated as otokoyaku, performers use masculine language forms within their performances, although it is made clear that this is not to carry over into their daily lives (Robertson 1998, 73).

The gendered language and terminology used in Takarazuka (such as 'musume'), reinforced normative familial roles as part of Kobayashi's structuring of his company. As is typical in the more traditional performing arts and other group structures in Japan, all Takarasiennes are referred to as 'seito' (生徒; student/s), while Kobayashi was referred to as 'otōsan' (お父 
さん; father) and their instructors as 'sensei' (先生; teacher). Takarazuka performers continued to call themselves students even after they graduated and began performing as professionals. This arguably denies them maturity, de-sexualising them in the permanent role of young women (Robertson 1998, 16; Yamanashi 2012, 36). Youthfulness and purity are key ideals which are reinforced by the strict relationship criteria which stipulate that performers must remain unmarried (Robertson 1998, 16). As distinct from the Kabuki ${ }^{4}$ term 'onnagata' (女形; lit., 'woman role'), which describes male actors playing female roles, the use of 'musume' (娘; lit., 'daughter', also used colloquially to mean 'young girl') creates an impression of innocence and dutifulness within a Japanese patriarchal family structure (Robertson 1998, 14).

As is the same in most performing arts forms, Takarazuka performances present idealised depictions of both men and women, only with an allfemale cast. Such performances can potentially reflect the constructed nature of gender as the performing body can exemplify, appropriate and denaturalise normative modes of masculinity and femininity. Takarazuka's practices-again, as in most theatre arts-demonstrate that enacting gender is a skill that is consciously taught and reinforced through repeated actions (Stickland 2004). This performance of gender has the potential to undermine a patriarchal conception of gender relations as it becomes clearer that gender is the result of learned behaviour and not biological difference. Beyond the stage, Takarazuka training instilled a regime of behavioural criteria so as to align the performers with Kobayashi's desire to produce "strictly wholesome entertainment" (Singer 1996, 162). But despite this gendered approach, the cultivation of personality in the performances and training in individual expression (although heavily coded) meant that Takarazuka moved beyond the focus of most women's colleges at the time, which was to prepare women for marriage and motherhood (Yamanashi 2012, 38). Nevertheless, Kobayashi's intention was not to empower women through their self-development but to make them more appealing as future wives and mothers. This would have also served a practical purpose by ensuring the success and profitability of the Revue as a business through the appeal of these idealised images to middleclass and conservative audiences.

The portrayal of gender and sexuality within Takarazuka exaggerates the gender constructions within Japanese society and stereotypically reflects dominant masculinity. Despite an all-female cast, the management and artistic direction of the company is controlled almost exclusively by men (Berlin 1991, 46). The storylines of Takarazuka plays are also male-centric, as female characters are cast in supporting roles for otokoyaku leads (Robertson 1998 , 12). Even though women perform the otokoyaku roles, Kobayashi indicated that his intention was to glorify masculinity and showed no concern for expanding the range of possible selves for women (Robertson 1998, 17). Clearly, entrenched social norms at the time made it relatively difficult for women to escape from social expectations that they would assume the role and responsibilities of housewife. According to Kobayashi, Takarazuka training is supposed to create the ideal wife, as it allows the performers to understand male desires through their portrayal of male characters, as well as understand 
how to successfully satisfy their husband's expectations through performing complementary female roles (Chen 2010, 55).

One of the most visible and lasting effects of Ōgi's time as a Takarasienne is the continued use of her stage-name, which became a permanent part of her identity and public persona during her political career. Before making her debut as a Takarasienne, each student must choose the stage name (芸 名) that she will use during her career, although birth names are maintained for private and legal purposes (Stickland 2004, 179). There is a strict process for the selection and approval of these names: they must reflect the aesthetic values of the School and must not be too similar to the student's original name or another performer's stage name. Inspiration is to be drawn from a variety of sources, including poetry and nature-both as a reflection of Kobayashi's literary tastes and as an allusion to the Takarasienne's artistic character (Stickland 2004, 180).

The selection of a name is intended to reflect the performer's persona and connect them with the principles of Takarazuka. In Ögi's case, the surname 'Ōgi' (扇) comes from the Japanese word for "folding fan," which is a key instrument used in Takarazuka choreography (Brau 1990, 85). Her personal name, 'Chikage' (千景), is a combination of the character for 'thousand' with the character for 'vista' or 'view'. Her stage name can thus be read as a poetic visual device to elicit an image of 'views of a thousand fans', symbolising the beauty of a Takarazuka performance. Ōgi's adoption of this stage name is emblematic not only of her professional development as a performer, but also of her growing agency and independence from her parents.

\section{MARRIAGE, MOTHERHOOD AND RETURNING TO FILM: LIFE AFTER TAKARAZUKA}

In 1957, Ögi retired from the Takarazuka Revue so that she could marry Kōtarō Hayashi [林 宏太郎; b. 1931], a famous Kabuki actor known publicly as Tōjūrō Sakata IV (四代目坂田藤十郎), who inherited the tradition from his family as is customary in Kabuki. They married in 1958 and Ōgi formally adopted his surname, becoming Hiroko Hayashi, while maintaining her Takarazuka stage name for her public persona. Ögi spent the year after marriage as a housewife before re-entering the entertainment industry and appearing in a range of television dramas, variety shows and commercials. While continuing her acting career she and Hayashi had two sons, born in 1959 and 1960, who later joined their father as Kabuki actors. Like most musumeyaku, Ōgi's retirement from Takarazuka at twenty-five years of age for the purpose of marriage and family-raising was considered natural. In the early days, Kobayashi was actively involved in organising "good" marriages for all performers at an appropriate age as determined by social norms, even if this conflicted with their individual aspirations (Robertson 1998, 17; see also Matsuo 2003, 96). ${ }^{5}$ Marriage was viewed as a desirable life goal and a key part of one's social identity, although this appears to be less so in contemporary Japan (Imamura 1990). 
Ōgi's legal surname became "Hayashi" in line with the custom of adopting a single surname for both spouses-usually but not always the husband'safter marriage. This symbolised her joining with her new family. Ōgi valued her role as a housewife and mother (Shimazaki 2006) and shifted her status and role expectations accordingly. At the same time, it was important for Ōgi to maintain her relationship with the Takarazuka stage, as indicated by her decision to retain her Takarazuka stage name after retiring from the company. This eventually became an asset in her political career as it sustained her professional identity and provided a tangible connection for voters, reminding them of her past performances as a musumeyaku.

From 1971 until 1977, Ōgi was co-host of the daytime television show "You at 3 o'clock” (三時のあなた), which she hosted alongside several other famous actresses including Yoshiko Ōtaka [1920-2014]. Garnering this role based on the popularity she had earned as a performer, Ōgi's experience with media personalities, including actors, singers and other performers, served her well in discussing popular culture issues for the show's main audience of housewives. At the time, gendered casting of female and male roles in mainstream television programming narrowed the scope of women's interests to the domestic sphere (Saito 2007). Daytime television was a relatively new concept and "You at 3 o'clock" separated itself from other television talk shows as there was an attempt to include discussions on contemporary news topics, such as the Vietnam War and the Israeli-Palestinian conflict. Although serious topics were typically hosted by male anchors, Ōgi's co-host Yoshiko Ōtaka had international experience as an actress and as a diplomat's wife, and conducted interviews with several international political leaders (Saito 2007). Nevertheless, gender roles on the show were clearly delineated, with the hosts expected to embody feminine characteristics such as physical beauty. Ōtaka expressed her reservations about her own selection as a host, saying "I suppose my appearance as a host served merely an ornamental purpose" (Yamaguchi and Fujiwara 2015, 285). With the theatrical communication skills developed during her time as a Takarasienne, Ōgi was able to effectively adapt to this new entertainment medium and expand her fan base.

\section{PERFORMING AS A POLITICIAN}

According to Newman (2008), each new generation finds ways to overcome the context-dependent circumstances they face. Ögi's long career as a politician suggests the effectiveness of her dextrous gender performance, arguably crucial in her widespread appeal to both her colleagues and voters as she gained positions of political power and prestige within a highly masculinised space. Based on the limitations Ōgi's generation of women faced, Ōgi's opportunities were enhanced when she learned as a Takarasienne to "observe, manipulate and modify orthodox gender roles for ... [her] own purposes" (Stickland 2004, 275), both on and off stage. Ögi's skill at representing a feminine identity through visual devices, such as mannerisms and clothing choices, helped her develop a successful campaign to appeal to conservative voters together with her male Party colleagues (Puwar 2004, 93). She also utilised male mentor support to ensure her inclusion in the inner circles, 
as external male patronage is one method for women to overcome career boundaries in the absence of family support (Lebra 2007b, 185).

In 1974, at the suggestion of the soon-to-be Prime Minister Takeo Fukuda [福 田 趃夫; 1905-1995] and while still working as a television host, Ögi decided to run for election. She was forty-four years of age at the time. After Fukuda became Prime Minister [1976-1978], Ögi successfully ran for election to the House of Councillors (Upper House) in 1977 as a member of the Liberal Democratic Party (自民党; LDP). Her father-in-law and husband had both objected when she had been approached to run for the LDP initially, deeming it “not suitable for a daughter-in-law of the Kabuki world” (梨園の嫁としてふさ わしくない) (Shimazaki 2006, 66). Before the 1977 election campaign, several male LDP members, including Fukuda, met with Ögi's family to show their support for her. After this, her father-in-law announced, "This time I would like to support my son's wife in the election” (おたくのお嫁さん、今度の参院選 に貸していただきたい) (Ōgi 2008, 232). Ōgi’s social networks and male LDP colleagues provided crucial support to help her overcome the strict gender roles enforced by her family. This was important as it enabled her to pursue her own goals unhindered by the conflict which would have occurred if she had challenged her family's wishes.

This was to be the beginning of a thirty-year (five-term) political career, making Ōgi one of the longest-serving female politicians in Japan. Her initial responsibilities included: Special Committee on the Environment (Public Nuisance Countermeasures and Preservation of the Environment) (1977); Special Committee on Traffic Safety member (1978); State Secretary for Science and Technology (1981); and Committee on Education (1985). This suggests the tendency to assign women "soft" subjects (such as childcare, science, consumer affairs, education, health) associated with "feminine" values, as opposed to the traditionally "masculine" areas of defence, foreign affairs and the economy (Puwar 2004, 89). These areas may have aligned with Ōgi's interests and been commensurate with her socialisation and experience, but such categorisation fails to recognise, and capitalise upon, the different perspectives women such as Ögi can bring to the more male-dominated policy areas (Phillips 1995, 62-3).

The consistently small percentage of women in the LDP indicates that it has not been particularly friendly to female candidates. The LDP began deploying female celebrity candidates in the 1970s, beginning with the famous actresses Akiko Santō [山東 昭子; b. 1942] and Yoshiko Ōtaka, who were candidates in the 1974 House of Councillors election. ${ }^{6}$ This was an early indicator of the increasingly common use of female 'talent' or celebrity candidates as a campaign strategy to mobilise and distract voters from difficult issues, such as the Lockheed bribery scandals in $1976 .{ }^{7}$

\footnotetext{
6 A recent example of this tactic are the 'Koizumi Children' (小泉チルドレン) of the 2005 election: 83 new LDP candidates, many of whom were young attractive female celebrities, were endorsed as part of a strategy to attract voters with young and famous faces.

7 From the 1950s to 1970s, officials from the US' Lockheed aerospace company bribed government officials and politicians in several nations in order to secure contracts, as the company was facing bankruptcy. Japan's LDP Prime Minister Kakuei Tanaka and his representatives received at least \$12 million from Lockheed. Lockheed also employed a Japanese war criminal because of his close connection to the LDP. When these dealings were uncovered, then-Prime Minister Tanaka was forced to resign, and was arrested and found guilty of violating Japan's foreign exchange laws.
} 
In 1977, the LDP was in a precarious position as it no longer held a clear majority in either house of the Diet. Forced to negotiate with other political parties, it endorsed female candidates with little political experience like Ōgi, which may have contributed to increasing the Party's popularity with female voters and renewing trust through an image of innocence (Derichs et al. 2006). This was not a serious effort to engage with female voters, however, as the LDP did little to mobilise women's votes, despite their consistently higher electoral numbers than men (Mackie 1989, 23-4). Overall, LDP policies and the dominant attitudes of male Party politicians exhibited contempt for the disadvantages faced by women and ignored their needs in the decisionmaking process. Instead, they aimed to exploit the image of femininity and the innocence of selected female candidates without actually changing the status quo (Derichs et al. 2006).

Ōgi's stage and media personality served her well upon her entry into politics. She was known in media as the "LDP Mascot Girl” (自民党のマスコットガー ル) and “Ex-Actress from Takarazuka” (宝塚出の女優あがり), and attracted headlines such as "A Beautiful Woman's Pulling Power rather than Political Power” (政治力より美人の吸引力) (Shimazaki 2006, 59). Ōgi recalled that during her election campaigns she was surrounded by supporters calling her name, thanks to her public exposure on "You at 3 O'Clock" (Ōgi 2008, 235). Ögi's sense of agency grew with her political successes, but paradoxically, rather than empowering Ōgi, her public image and the LDP's strategic use of her identity undermined her achievements and abilities.

Scholars have identified three aspects of electioneering which are viewed as essential in winning an election: jiban (地盤; support), kanban (看板; name recognition) and kaban (鞄; lit., 'bag', referring to financial support by evoking the image of a bag full of money) (Kubo and Gelb 1994, 133). Women face significant hurdles throughout their life course that reduce their access to the necessary opportunities for a successful political career (Kato 2009). Even so, in Ōgi's case her career in show business and her marriage to a famous Kabuki actor allowed her to fulfil two of the above criteria: jiban and kanban. Ögi's fame increased her chance of election (and maintaining her seat), reduced the Party's financial expenses (as they were campaigning for a known candidate), and made her re-election in the Upper House more likely (as she was able to appeal across constituencies, which has proven a more successful strategy for female candidates) (Eto 2010, 183; Kubo and Gelb 1994, 133). Her conservative attitudes and performance of traditional gender roles aligned with the LDP, which she had also supported before her election (Ōgi 2008, 226), and underpinned Ōgi's rise by allowing her to overcome the obstacles presented by her parents' and husband's objections to reach her goals.

Ōgi was voted out of her seat in 1989 but continued to campaign and won back her position in the Upper House in 1993. In 1994, she left the LDP in favour of the Japan Renewal Party (新生党; JRP), which was created the previous year when LDP reformers Tsutomu Hata [羽田 孜; b. 1935] and Ichirō Ozawa [小沢 一郎; b. 1942] defected and began their own party. The JRP had been instrumental in the LDP's brief fall from power in 1993, as it had joined with six other smaller parties to form a coalition government (Hori 2006). One 
of Ōgi's aims was to simplify the Constitution by clarifying controversial aspects-particularly Article 9, which did not permit the use of land, sea or air forces to settle international disputes-and to reform educational policy to address issues such as bullying (Maeda 2000). The LDP had long manipulated the terminology found in Article 9 to allow them to build up significant military forces (i.e., Japan Self-Defense Force); they also exploited lax provisions to engineer the electoral system to their advantage (McElwain 2008) and interfered with job assignment procedure in the courts to influence the selection of court judges (Ramseyer and Rasmusen 2010, 125-27). Ōgi had ethical concerns about these issues (Maeda 2000). In contrast, the JRP appeared to offer Ögi the opportunity to achieve her desired reforms (as the LDP had reneged on its promises of reform) and this was her main motivation for leaving the LDP.

In December 1994, the JRP formed the New Frontier Party (新進党; NFP), comprising several smaller political parties with diverse platforms. In 2000, Ōgi then founded the New Conservative Party (保守新党; NCP) in which she promised to lay the "moral ground" for Japan (Maeda 2000). The NCP became part of a ruling coalition with the LDP and the Kōmeitō party (公明党). Under the coalition, Ōgi became Minister for Construction (2000), Minister for Transport (2000) and Minister for Land, Infrastructure and Transport (2001) (Prime Minister of Japan 2002a). In this coalition government, Ögi's party was able to negotiate for her desired reforms. She also pragmatically agreed to merge with the LDP if the NCP's performance made the achievement of these aims unlikely. The NCP was dissolved in 2002 and Ogi returned to the LDP shortly after in 2003.

The following year, Ögi was appointed as the 26th President of the House of Councillors, becoming the first woman in Japan to achieve this position (Puwar 2004). Ogi used this role to meet with world leaders in Africa, the United States and China to foster and promote cooperation between nations, with a focus on improving Japan-China relations ( $\mathrm{Mu}$ 2006). Then-President $\mathrm{Hu}$ Jintao described Ōgi's visit to China, the first Japanese representative at that level since 1999, as a "turning point" in China-Japan relations (Lu 2006). She was honoured for her contributions with several awards, including Japan's Grand Cordon of the Order of the Rising Sun (旭日大綬章) in 2003 as the first female recipient, ${ }^{8}$ South Korea's Order of Diplomatic Service Merit, Grade One (修交勲章光化章) in 2005 and China's Order of the Brilliant Star, First Class (一等景星勲章) in 2008 (Ōgi 2008, 144-45).

\section{PERFORMING GENDER IN POLITICS}

In this section, I will compare and contrast Ōgi's appearance in a visual analysis of Cabinet photographs. Costuming and colour choice play a key role in the representation of gender within Takarazuka performances, and Ōgi utilised similar principles throughout her political career, often appearing in soft colours or variants of pink and red. However, striking a balance between performing femininity and asserting one's professional capability in 
the political world is more complex than simply choosing the 'right' colour. Over-emphasising one's femininity can result in restricting one's political assignments to "women's issues" (Dalton 2008b, 56), while challenging them can make one an obvious target of criticism in terms of political suitability (Flicker 2013). Nonetheless, Ōgi's long and successful tenure as a politician, and particularly her appointment to traditionally male-dominated roles, shows that she skilfully navigated this double bind to maintain a balance of femininity and professional credibility.

Dress is a crucial aspect in the performance of gender in Japan (Monden 2015, 6), as it is elsewhere. Clothing and aesthetic appearance in Japanese society play a foundational role in defining the boundary between self and society, and in perpetuating gender norms (Mackie 2009). Masculinity is bound to and codified in suit-based clothing as the uniform dress code for male politicians and white-collar workers, allowing for little visual variation aside from the colour of one's tie. This uniformity also existed with traditional forms of male dress prior to the adoption of the Western morning suit over the kimono in the Meiji period. The context of the suit's introduction also associated the male wearer with progress and modernisation, whereas the female kimono remained a symbol of traditional Japan. In this way, the male body and masculinity have consistently been defined against and separated from the 'feminine' in Japan (Slade 2009, 96-97). In the suited male figure, the emphasis on the chest and shoulders symbolises "reserve, stature and efficiency" (Monden 2015, 24) and reinforces the status associated with this posture in the public sphere.

Women's physical absence from politics until electoral rights were granted in 1945 meant that strict dress codes for women in the political sphere were not firmly established. As women are given a greater range of dress choices, many female politicians have used their dress and appearance to portray certain images to voters about their character and their position within social norms. There is still a large gender disparity among Japanese parliamentary figures, with female politicians-and their generally more colourful clothing-in the minority. As a result, the colours worn by female politicians stand out beside the uniform colours (generally black) of their male colleagues' suits. Ōgi used this to her advantage, ensuring that her aesthetics of dress communicated an adherence to the feminine. Her colourful presence also emphasises her difference in a masculine space (Flicker 2013, 205). This difference is accepted because Ōgi successfully uses dress to conform to the normative expectations of her party.

In five Cabinet photographs taken between 2000 and 2002, Ōgi appears in either traditional Japanese kimono (Figures 3 and 5) or Western-style evening dresses and ladies' suit jackets (Figures 1,2 and 4). The kimono is a "marked feminine costume" strongly related to Japanese identity and tradition (Goldstein-Gidoni 1999, 351). Ōgi's choice to wear kimono reflects traditional Japanese aesthetic values and feminine beauty ideals. There are customary stipulations on kimono style, patterns and colours based on context, age and marital status (Sato 2010); the subdued colours of Ōgi's kimono would be 
seen as a culturally suitable choice for a mature-age woman (Bolich 2007, 211; Sato 2010,24). Western attire, in contrast, is less attached to traditional codes and tends to be associated with modernity and progress (Goldstein-Gidoni 1999, 351). In alternating between Japanese and Western dress, Ōgi asserts her Japaneseness and her femininity, while at the same time reminding the viewer of her political capacity in a modern world. Her group positioning in the foreground of the photographs (in recognition of her long tenure as a politician) enhances her visibility. Ogi wears her hair short in all five photographs, which contrasts with the long hair of her Takarazuka days. While long hair is traditionally associated with feminine youth and beauty, short hair in women may be seen as symbolising maturity, and hence as more appropriate for the political sphere.
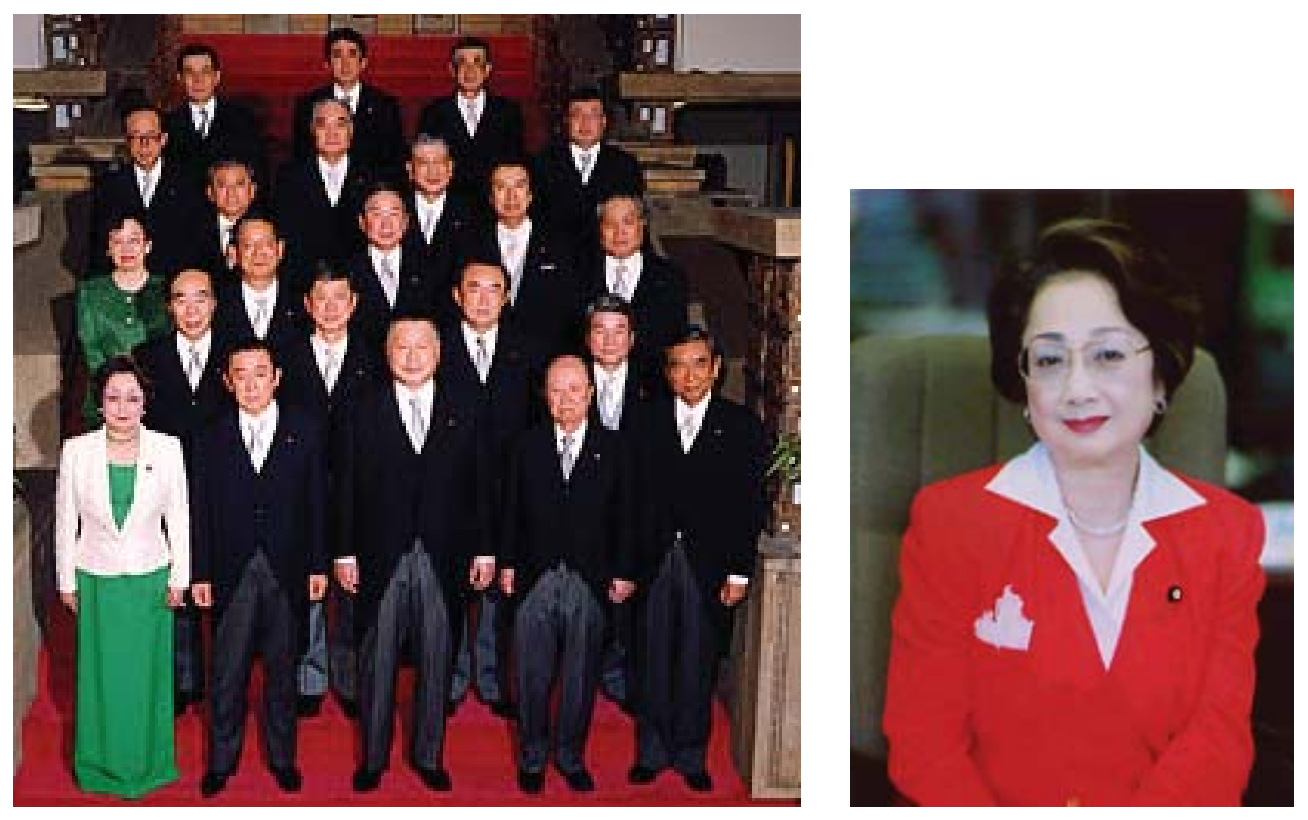

Figure 1 (left): Commemorative photo of the Second Tsugimori Cabinet Reshuffle, 5th December, 2000. Ōgi: front row, left; Kawaguchi: third row, left. (Source: Prime Minister of Japan 2000)

Figure 2: Chikage Ōgi's official profile picture (Source: Prime Minister of Japan 2002a)

Figure 1 features Ōgi in 2000, in her first appointment to the Cabinet as Minister for Transport while she was leader of the NCP. Yoriko Kawaguchi [川口順子; b. 1941] and Ōgi both appear in emerald green. Kawaguchi's body is obscured from view behind Ōgi, but the formal lines of her attire are visible. Ögi's eye-catching combination of a green, floor-length Western-style gown with a white suit jacket hides the body and emphasises flow, as does a kimono (Slade 2009, 97). The distinct framing of her upper body as the suit jacket outlines her shoulders is a modern signifier of professionalism and business. Ōgi also wears a suit jacket in Figure 2, which-as her official profile pictureis arguably the most prominent visual representation of her as a political figure. As in this image, Ōgi is often pictured in a red suit jacket with a white blouse underneath: the national colours of Japan.

Figure 3 shows Ōgi in a pale gold kimono, the smooth lines and folds of which conceal the contours of the body. Kimono as formal wear for women on important occasions is a symbol of femininity and national tradition 
(Goldstein-Gidoni 1999, 351). In contrast, the Western suit symbolises "national action and achievement" (Goldstein-Gidoni 1999, 351). Due to her placement in the photo, Ōgi's kimono adds colour to the mostly dark suits surrounding her and also draws attention away from her colleague Kawaguchi, who wears darker colours.

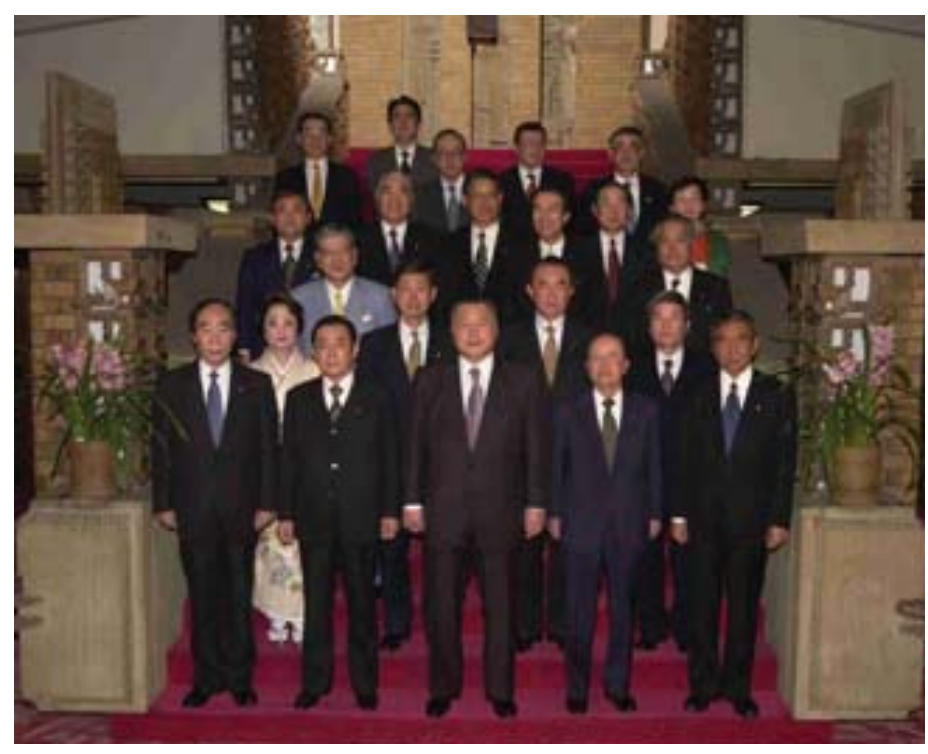

Figure 3: Commemorative photo of the Second Tsugimori Cabinet Reshuffle, 6th January, 2001. Ōgi: second row, left; Kawaguchi; fourth row, right. (Source: Prime Minister of Japan 2001b).

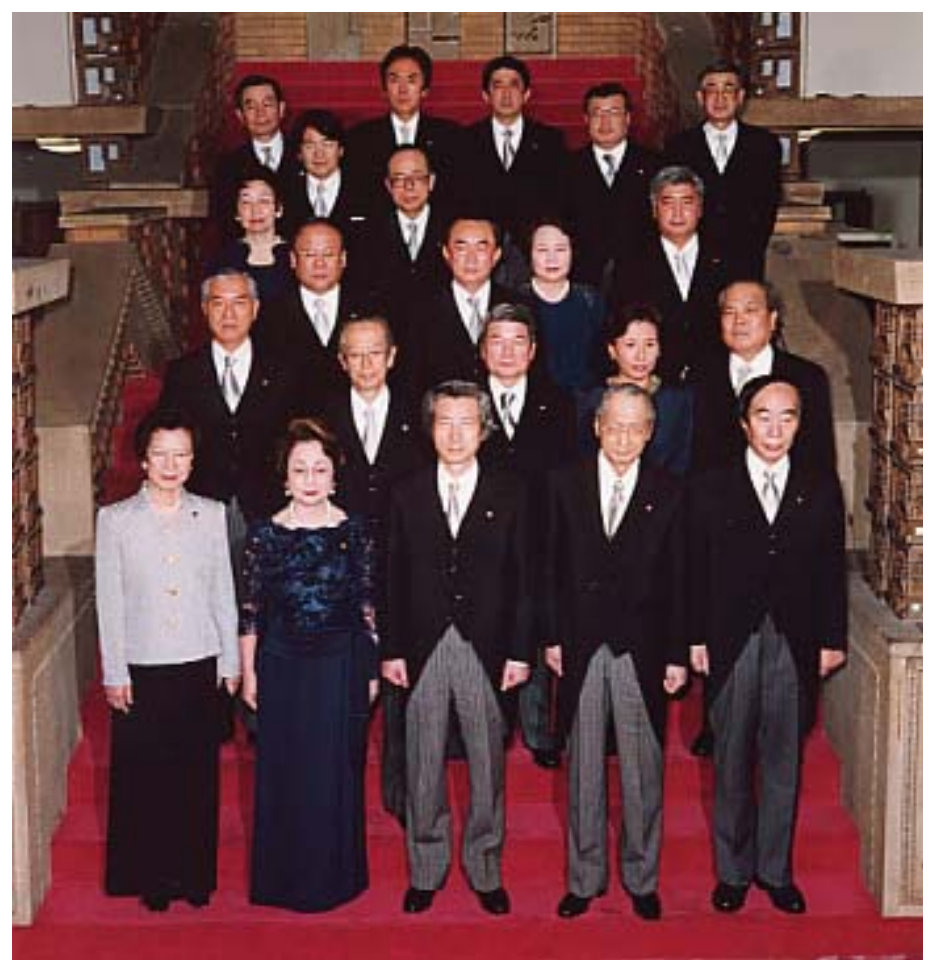

Figure 4: Primary Koizumi Cabinet, 26th April, 2001. Ōgi: front row, second from left; Kawaguchi: front row, left; Tanaka: second row, fourth from left; Toyama: third row, third from left; Moriyama: fourth row, left. (Source: Prime Minister of Japan 2001a)

The 2001 Cabinet under Jun'ichirō Koizumi featured a record number of female ministers, with Makiko Tanaka [田中 眞紀子; b. 1944], Mayumi Moriyama [森山 眞弓; b. 1927] and Atsuko Toyama [富山 敦子; b. 1938] joining Ōgi and 
Kawaguchi. Unlike the Cabinet photographs, Ōgi and the three newcomers all dress in a dark navy blue, with the exception of Kawaguchi in black and grey. Ögi's front-row positioning next to Kawaguchi gives her optimum visibility, while the navy-coloured dresses of her female colleagues blend in with men's darker suits. Perhaps their choice of dark colours on this occasion was a conscious decision to present a more disciplined, united image of the Party. Kawaguchi's positioning in the front row and her grey suit jacket with padded shoulders present a bold, businesslike appearance. These differences set her apart from both her female and male counterparts. Ōgi's refined navy evening dress with lace brocade sleeves shares the colour scheme adopted by her other female colleagues, but the dress is more feminine than the sharper shoulders on Tanaka's navy dress, for example. Here, Ōgi's flowing dress with softened shoulders and concealed body does not borrow any masculine aesthetic elements and reinforces a feminine ideal rooted in traditional aesthetic standards (Goldstein-Gidoni 1999, 360-62).

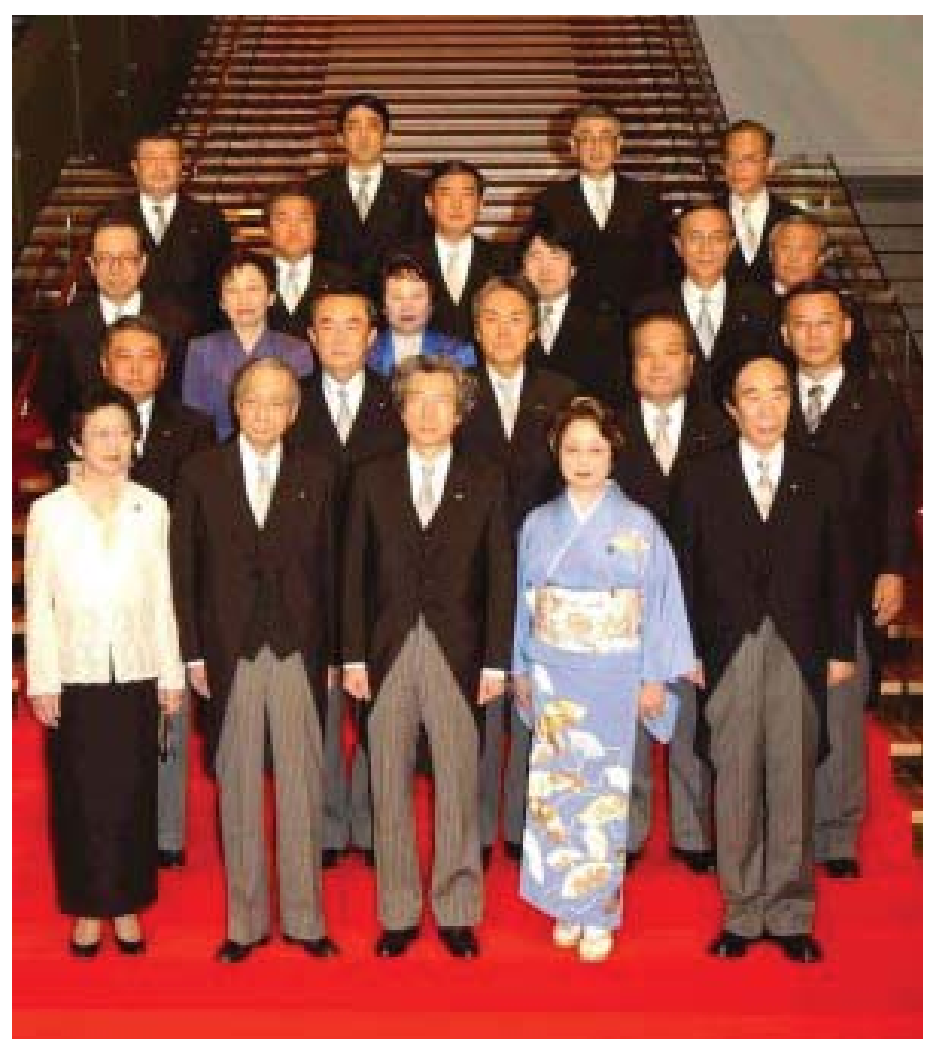

Figure 5: Commemorative photo of the Primary Koizumi Cabinet First-Order Reshuffle, 30th September, 2002. Ōgi; front row, fourth from left; Kawaguchi: front row, left; Moriyama: third row, second from left; Toyama: third row, third from left. (Source: Prime Minister of Japan 2002b)

In Figure 5, Ōgi wears a powder-blue patterned kimono and geta (下駄). ${ }^{9}$ She is distinct as the only Cabinet member in traditional Japanese dress. Although all women are visible and wear blue hues, Ōgi's appearance contrasts with those of Kawaguchi, Moriyama and Toyama who all wear suit jackets. The time and restraint involved in wearing a kimono suggest mores of endurance and patience, which are cherished in Japanese traditions (Goldstein-Gidoni 1999, 161-62). Both here and in the photos above, Ōgi's choice of dress 
is unique and stands as a clear reminder that she represents the core of normative Japanese femininity. The above images illustrate how women can use costuming to communicate ideas about their social and gender roles and personalities, which are then reinforced by their performances in the public sphere (Puwar 2004; Dalton 2008b).

Such readings of self-presentation by present-day politicians, both female and male, can be problematic for both the empowerment of female politicians and their effects on the wider community. Despite Ōgi's dexterity in deploying a feminine image as a method of winning votes and intra-political support, her public statements have perpetuated stereotypes about women's roles as wives and mothers. One example is her remark following the birth of Princess Kiko's child: "We women should learn from the princess's courage in overcoming the pain of a caesarian section and giving birth to her third child" (China Daily 2006)..$^{10}$ Ogi's statement reinforces normative expectations that women will bear children. In her own life also, Ōgi embraced the normative expectation of being a supportive wife (Shimazaki 2006, 70), possibly to the detriment of her career. On the other hand, by perpetuating the normative gender expectations supported by many Japanese male and female politicians, she was able to progress in her career. Recognition of this may lie behind her public response to her husband's infidelity ("I know that girl. She is intelligent and I favour her, too. A husband not attractive to women would be boring"), and her view on another parliamentarian's affair ("For a man, it is better that he is virile. My husband, too, has had his share of affairs") (Kwan 2000), although it is impossible to determine whether these comments are born from political opportunism or actually reflect her true beliefs. What can be safely assumed is that Ōgi is strongly conservative in her values, and is adept at manipulating her public image to appeal to conservative voters, her Party members and LDP backers.

\section{CONCLUSION}

Ōgi provides an example of a female politician who embraced traditional and conservative notions of femininity and used these to build her career. In this paper, I have analysed the ways in which past experiences and sociocultural contexts played a key role in conditioning Ōgi's access to opportunities. Her family was a strong source of socialisation and directed her toward becoming a good wife. These attitudes affected her degree of agency and ability to make independent choices for her life course (Hutchinson 2001, 27-8). Despite the objections from her father, father-in-law and husband, Ōgi utilised the skills she developed through her Takarazuka training to deploy an image of femininity, and leveraged her experience in show-business to appeal to voters and to members within the masculine culture of the LDP. Ultimately, it is this that allowed her to become a successful politician. 


\section{ACKNOWLEDGEMENTS}

Appreciation is extended to my $\mathrm{PhD}$ supervisor, Dr Mio Bryce, for her feedback and encouragement. Support for this research was contributed by a Macquarie University Research Excellence Scholarship (MQRES).

\section{APPENDIX I}

\section{Chikage Ōgi Chronology}

1933 Born Hiroko Kimura (木村 寛子) in Kobe, Hyogo prefecture

1952 Graduates from Hyogo Prefectural Kobe High School and enters

Takarazuka Music School

1954 Joins Takarazuka Revue as a musumeyaku, taking the stage name ‘Chikage Ōgi’ (扇 千景)

1957 Retires from Takarazuka Revue in order to marry

1958 Marries Kabuki actor Kōtarō Hayashi (林 宏太郎), whose stage name is Tōjūrō Sakata IV (四代目 坂田 藤十郎). Changes official name to Hiroko Hayashi (林 寛子)

1959 Re-enters entertainment industry, appearing in television dramas, variety shows and commercials Birth of first son, Tomotarō Hayashi (林 智太郎), whose stage name becomes Nakamura Kanjaku IV (四代目 中村鴈治郎)

1960 Birth of second son, Kōtarō Hayashi (林 宏太郎), whose stage name becomes Nakamura Senjaku III (三代目 中村 扇雀)

1971 Becomes regular co-host of the daytime television show, "You at 3 o'clock" (三時のあなた)

1974 Approached by Takeo Fukuda (福田 趣夫) to run in the House of Councillors election

1977 Retires from hosting "You at 3 o'clock"

Endorsed by Liberal Democratic Party (自民党; LDP)

Elected to the Upper House, also known as the House of Councillors (参議 院)

Member, Special Committee on the Environment (Public Nuisance

Countermeasures and Preservation of the Environment) (公害及び環境保全 特別委員)

1978 Director, Special Committee on Traffic Safety (交通安全対策特別委員)

1979 Director, Committee on Cabinet (内閣委員会理事)

Member, Special Committee on Energy（エネルギー対策特別委員） 
1980 Director, Special Committee on Science and Technology

(自民党科学技術部会長)

Member of Japanese National Commission for UNESCO

(日本ウネスコ国内委員)

1981 State Secretary, Science and Technology (科学技術政務次官)

1983 Director, Special Committee on Science and Technology (科学技術部会長)

1985 Chairperson, Committee on Education (参議院文教委員長)

1989 Voted out of Upper House

1993 Re-elected to Upper House

Director, Special Committee on Science and Technology (科学技術部会長)

1994 Leaves LDP to join the Japan Renewal Party (新生党; JRP)

JRP merges into New Frontier Party (新進党; NFP)

1995 Director, Committee on Discipline

Member, Committee on Education (文教委員)

Member, Special Committee on Science and Technology (科学技術特別委員)

1997 Member of National Land Council (国土審議委員)

Member of Special Committee on Development of the Tokyo Metropolitan

Area (首都圈整備特別委員)

1999 Member, Committee on Education, Culture and Science (文教科学委員)

Member, Deliberative Council on Political Ethics (政治倫理審査委員)

2000 Founds New Conservative Party (保守新党; NCP), which joins with LDP and Kōmeitō (公明党) to form ruling coalition

Minister for Construction (建設大臣)

Minister for Transport (運輸大臣)

Director-General of the National Land Agency (国土庁長官)

Director-General of the Hokkaido Development Agency (北海道開発庁長官)

2001 Minister for Construction (建設大臣)

Minister for Land, Infrastructure and Transport (国土交通大臣就任)

2002 NCP dissolves

2003 Returns to LDP

Awarded Japan's Grand Cordon of the Order of the Rising Sun

(旭日大綬章) (first female recipient)

2004 Appointed 26th President of the House of Councillors (第26代 参議院議長), becoming the first woman to attain this position

2005 Awarded South Korea’s Order of Diplomatic Service Merit, Grade One (修交勲章光化章)

2006 Lead a delegation to China as President of the House of Councillors 
2008 Awarded China’s Order of the Brilliant Star, First Class (一等景星勲章)

\section{APPENDIX II}

\section{Glossary of Japanese Terms}

\section{Geta [下䭾]}

Traditional Japanese sandals with an elevated base worn with kimono

Ie [家]

Stem-family system; sometimes referred to as ie seido [家制度]

Jiban [地盤]

Support or power base; known in Japan as one of the three criteria for becoming a successful politician

\section{Kaban [鞄]}

Financial support (lit., 'bag', referring to financial support by evoking the image of a bag full of money); known in Japan as one of the three criteria for becoming a successful politician

\section{Kanban [看板]}

Name recognition (lit., 'billboard'); known in Japan as one of the three criteria for becoming a successful politician

Kiyoku, tadashiku, utsukushiku [清く、正しく、美しく]

The Takarazuka motto, "With purity, honesty, [and] beauty"

\section{Musume [娘]}

Daughter; also used colloquially to mean 'young girl'

\section{Musumeyaku [娘役]}

Lit., 'daughter role'; female actor who plays young female roles in Takarazuka performances

Onnagata [女形]

Male actor who plays female roles in Kabuki theatre

\section{Onnayaku [女役]}

Lit., 'woman role'; female actor who has graduated to older female roles in Takarazuka performances

Otokoyaku [男役]

Lit., 'male role'; female actor who plays male roles in Takarazuka performances

\section{Otōsan [お父さん]}

Father 


\section{REFERENCES}

Banerjee, P. 2010. "Preface." In Women in Peace Politics, edited by P. Banerjee, xi-xix. New Delhi: Sage Publications India.

Bengsten, V. L. and K. R. Allen. 1993. "The Life Course Perspective Applied to Families Over Time." In Sourcebook of Family Theories and Methods: A Contextual Approach, edited by P. G. Boss, W. J. Doherty, R. LaRossa, W. R. Schumm and S. K. Steinmetz, 469-99. New York: Springer.

Berlin, Z. 1991. “The Takarazuka Touch.” Asian Theatre Journal 8 (1): 35-47. http://dx.doi.org/10.2307/1124165.

Bolich, G. G. 2007. Transgender History \& Geography: Crossdressing in Context, Volume 3. Raleigh, North Carolina: Psyche's Press.

Brau, L. 1990. “The Women's Theatre of Takarazuka.” TDR (1988-) 34 (4): 79-95. http://dx.doi.org/10.2307/1146045.

Chen, Y. 2010. "Gender and Homosexuality in Takarazuka Theatre: Twelfth Night and Epiphany." Performing Ethos 1 (1): 53-67. http://dx.doi.org/10.1386/ peet.1.1.53_1

China Daily. 2006. "Royal Birth Raises Profile of Princess Kiko.” September 7. Accessed 22 October, 2015. http://www.chinadaily.com.cn/world/ 2006-09 /07/content_683778.htm.

Dalton, E. 2008a. "A Masculinised Party Culture: Obstacles Facing Women in Japan's Liberal Democratic Party." Paper presented at the 17th Biennial Conference of the Asian Studies Association of Australia, Melbourne, Australia, July 1-3.

Dalton, E. 2008b. "The Utilization of Discourses of Femininity by Japanese Politicians: Tanaka Makiko Case Study." Graduate Journal of Asia-Pacific Studies 6 (1): 51-65.

Dalton, E. 2011. "The LDP and the Maintenance of Gender Inequality in Japanese Politics." PhD dissertation, University of Wollongong.

Dalton, E. 2015. Women and Politics in Contemporary Japan. New York: Routledge.

Derichs, C., A. Fleschenberg and M. Hüstebeck. 2006. "Gendering Moral Capital: Morality as a Political Asset and Strategy of Top Female Politicians in Asia." Critical Asian Studies 38 (3): 245-70. http://dx.doi.org/10.1080/14672710600 869665

Elder, G. H. 1998. "The Life Course as Developmental Theory." Child Development 69 (1): 1-12. http://dx.doi.org/10.2307/1132065. 
Eto, M. 2010. "Women and Representation in Japan: The Causes of Political Inequality." International Feminist Journal of Politics 12 (2): 177-201. http://dx.doi.org/10.1080/14616741003665227

Flicker, E. 2013. "Fashionable (Dis-)Order in Politics: Gender, Power and the Dilemma of the Suit." International Journal of Media \& Cultural Politics 9 (2): 201-19. http://dx.doi.org/10.1386/macp.9.2.201_3.

Goldstein-Gidoni, O. 1999. "Kimono and the Construction of Gendered and Cultural Identities." Ethnology 38 (4): 351-370. http://dx.doi.org/10.2307/3773912

Hori, H. 2006. The Changing Japanese Political System: The Liberal Democratic Party and the Ministry of Finance. London: Routledge.

Hutchinson, E. D. 2001. "A Life Course Perspective." In Dimensions of Human Behaviour: The Changing Life Course, edited by E. D. Hutchinson, 1-38. Los Angeles: Sage Publications.

Imamura, A. 1990. “The Japanese Family.” Asia Society: 7-17.

Iwao, S. 1993. The Japanese Woman: Traditional Image and Changing Reality. New York: The Free Press.

Japan Today. 2014. “Tokyo Assemblywoman Heckled on Why She Isn't Married or Having Children.” 20 June. Accessed 21 June, 2014. http://www.japantoday. com/category/politics/view/tokyo-assemblywoman-heckled-about-whyshe-isnt-married-or-having-children.

Kato, S. 2009. Hereditary Lawmakers in an Era of Politically Led Policymaking (1). The Tokyo Foundation. Accessed 5 April, 2015. http://www.tokyofoundation. org/en/articles/2009/hereditary-lawmakers-in-an-era-of-politically-ledpolicymaking-1.

Kobayashi, K. [小林 公一]. 2014. Takarazukageki 100-nenshi niji no hashi watari tsuzukete (jinbutsu hen) [宝塚歌劇100年史 虹の橋 渡り続けて (人物編) ]: Hankyū komyunikēshonzu [阪急コミュニケーションズ].

Kubo, K. and J. Gelb. 1994. "Obstacles and Opportunities: Women and Political Participation in Japan." In Women of Japan and Korea: Continuity and Change, edited by J. Gelb and M. L. Palley, 120-49. Philadelphia: Temple University Press.

Kwan, W. K. 2000. "For a Man, it is Better that he is Virile. My Husband Too has had his Share of Affairs." The Straits Times, October 28. Accessed 20 October, 2015. http://eresources.nlb.gov.sg/newspapers/Digitised/Issue/ straitstimes20001028-1.aspx.

Lebra, T. 2007a. "Confucian Gender Roles and Personal Fulfillment for Japanese Women." In Collected Papers of Takie Lebra: Identity, Gender and Status in Japan, edited by T. Lebra, 248-63. North Yorkshire, England: Global Oriental. http://dx.doi.org/10.1163/ej.9781905246175.i-439.127 
Lebra, T. 2007b. "Japanese Women in Male-Dominant Careers: Cultural Barriers and Accommodations for Sex-Role Transcendence." In Collected Papers of Takie Lebra: Identity, Gender and Status in Japan, edited by T. Lebra, 177-95. North Yorkshire, England: Global Oriental. http://dx.doi.org/ 10.1163/ej.9781905246175.i-439.112

Lu, H. 2006. China, Japan Set Up Regular Exchange Mechanism. Accessed 14 May, 2016. http://news.xinhuanet.com/english/2006-10/17/content_5213419.htm.

Mackie, V. C. 1989. “A New Age for Women and Politics in Japan?” Japanese Studies 9 (3): 23-26.

Mackie, V. C. 2009. “Transnational Bricolage: Gothic Lolita and the Political Economy of Fashion." Intersections: Gender and Sexuality in Asia and the Pacific, 20. Accessed 15 October, 2015. http://intersections.anu.edu.au/ issue20/mackie.htm.

Maeda, T. 2000. "Ogi's New Conservatives Aim to Lay Japan's 'Moral Ground'." June 17. Accessed 20 October, 2015. http://www.japantimes.co.jp/news/2000/ 06/17/news/ogis-new-conservatives-aim-to-lay-japans-moral-ground/.

Matsuo, H. 2003. The Transition to Motherhood in Japan: A Comparison with the Netherlands. Amsterdam: Rozenberg Publishers.

McElwain, K. M. 2008. "Manipulating Electoral Rules to Manufacture Single-Party Dominance." American Journal of Political Science 52: 32-47.

Monden, M. 2015. Japanese Fashion Cultures: Dress and Gender in Contemporary Japan. London: Bloomsbury Academic.

Morton, W. S. and J. K. Olenik. 2005. Japan: Its History and Culture. 4th edition. New York: McGraw-Hill Books.

Mu, X. 2006. Top Advisor Outlines Development of China-Japan Relations. Accessed 13 February, 2016. http://www.gov.cn/english/2006-10/16/content_414909. htm.

Newman, K. 2008. "Rising Angst? Change and Stability in Perceptions of Economic Insecurity." In Laid Off, Laid Low: Political and Economic Consequences of Employment Insecurity, edited by K. Newman, 74-101. New York: Columbia University Press and The Social Science Research Council.

Nocedo, A. M. A. 2012. "The 'Good Wife and Wise Mother' Pattern: Gender Differences in Today's Japanese Society." Crítica Contemporánea. Revista de Teoría Politica (November): 156-169. http://www.fcs.edu.uy/ archivos/Ara\%C3\%BAjo(1).pdf.

Ōgi, C. [扇 千景]. 2001. “Dekiru koto dekinai koto [できることできないこと].” Tokyo: Nihon Keizai Shimbun Publishing Company.

Ōgi, C. [扇 千景]. 2008. “Tsuma no rirekisho [妻の履歴書].” In Fūfu no rirekisho [夫 婦の履歴書], edited by T. Sakata [坂田 藤十郎] and C. Ōgi [扇 千景]. Tokyo: Nihon Keizai Shimbun Publishing Company. 
Prime Minister of Japan and His Cabinet. 2000. “Dai niji Mori naikaku” [第2次森 内閣]. Accessed 1 February, 2016. http://www.kantei.go.jp/jp/rekidai/ kakuryo/86-1.html.

Prime Minister of Japan and His Cabinet. 2001a. "Dai ichiji Koizumi naikaku” [第1 次小泉内閣]. Accessed 1 February, 2016. http://www.kantei.go.jp/jp/rekidai/ kakuryo/87.html.

Prime Minister of Japan and His Cabinet. 2001b. “Dai niji Mori naikaku” [第2次森 内閣]. Accessed 1 February, 2016. http://www.kantei.go.jp/jp/rekidai/ kakuryo/86-1new.html.

Prime Minister of Japan and His Cabinet. 2002a. "Minister of Land, Infrastructure and Transport: Chikage Oogi”. Accessed 18 October, 2015. http://japan. kantei.go.jp/koizumidaijin/020930/10ogi_e.html.

Prime Minister of Japan and His Cabinet. 2002b. "Dai ichiji Koizumi naikaku” [第1 次小泉内閣]. Accessed 1 February, 2016. http://www.kantei.go.jp/jp/rekidai/ kakuryo/87-1.html.

Puwar, N. 2004. Space Invaders: Race, Gender and Bodies out of Place. Oxford, New York: Berg.

Ramseyer, J. M. and E. B. Rasmusen. 2010. Measuring Judicial Independence: The Political Economy of Judging in Japan. Chicago: University of Chicago Press.

Reitan, R. 2011. "Claiming Personality: Reassessing the Dangers of the 'New Woman' in Early Taishō Japan." Positions 19 (1): 83-107. http://dx.doi. org/10.1215/10679847-2010-025.

Robertson, J. 1991. "Theatrical Resistance, Theatres of Restraint: The Takarazuka Revue and the 'State Theatre' Movement in Japan." Anthropological Quarterly 64 (4): 165-77. http://dx.doi.org/10.2307/3317210.

Robertson, J. 1992. "The Politics of Androgyny in Japan: Sexuality and Subversion in the Theater and Beyond." American Ethnologist 19 (3): 419-42. http:// dx.doi.org/10.1525/ae.1992.19.3.02a00010

Robertson, J. 1998. Takarazuka: Sexual Politics and Popular Culture in Modern Japan. Berkeley: University of California Press.

Rosenthal, C. S. 2008. "Climbing Higher: Opportunities and Obstacles within the Party System." In Legislative Women: Getting Elected, Getting Ahead, edited by B. Reingold. Colorado, USA: Lynne Reiner Publishers.

Saito, S. 2007. "Television and the Cultivation of Gender-Role Attitudes in Japan: Does Television Contribute to the Maintenance of the Status Quo?" Journal of Communication 57 (3): 511-31.

Sato, C. J. 2010. "Regarding Fashions in 20th Century Women's Kimono." Masters thesis. RMIT University. 
Shimazaki, K [島崎 今日子]. 2006. “Seijika一Ōgi Chikage: hiirō o koenai hiroin” [政 治家一扇千景：ヒーローを超えないヒロイン]. In Kono kuni de onna de aru to iu koto [この国で女であるといらこと], 57-70. Tokyo: Chikuma shobō [筑摩書房].

Singer, J. 1996. “The Dream World of Takarazuka.” Japan Quarterly 43 (2): 162-81.

Slade, T. 2009. Japanese Fashion: A Cultural History. Oxford: Berg.

Statistics Bureau of Japan. 2015. Statistical Handbook of Japan. Ministry of Internal Affairs and Communications. Accessed 1 August, 2015. http://www.stat. go.jp/english/data/handbook/c0117.htm.

Stickland, L. R. 2004. "Gender Gymnastics: Performers, Fans and Gender Issues in the Takarazuka Revue of Contemporary Japan." PhD dissertation, Murdoch University.

Tachibanaki, T. 2010. The New Paradox for Japanese Women: Greater Choice, Greater Inequality. Translated by M. E. Foster. Tokyo: International House of Japan Inc.

Takarazuka Music School. 2015. Takarazuka Music School. Accessed 22 October, 2015. http://www.tms.ac.jp/english/about.html.

Ueda, Y. [上田 善次]. 1974. Takarazuka sutā: sono engi to bungaku [宝塚スター:その 演技と美学]. Tokyo: Yomiuri shinbunsha [読売新聞社].

Ueno, C. 2009. The Modern Family in Japan: Its Rise and Fall. Balwyn North, Vic: Trans Pacific Press.

United States Strategic Bombing Survey. 1947. Effects of Air Attack on Osaka, Kobe, Kyoto. U.S. Govt. Print. Off.

Uno, K. 2005. "Womanhood, War, and Empire: Transmutations of 'Good Wife, Wise Mother' before 1931.” In Gendering Modern Japanese History, edited by B. Maloney and K. Uno, 493-519. Cambridge: Harvard University Press.

Yamaguchi, Y. and S. Fujiwara. 2015. Fragrant Orchid: The Story of My Early Life. Translated by C. Chang. Honolulu: University of Hawai'i Press.

Yamanashi, M. 2012. A History of the Takarazuka Revue Since 1914. Leiden: Global Oriental. 